\title{
A case of linear syringocystadenoma papilliferum of the axilla: A rare location
}

\author{
Aksillar yerleșim gösteren bir lineer siringokistadenoma papilliferum olgusu:
} Nadir bir lokalizasyon

\section{Serap Güneș Bilgili, ๑ İbrahim Halil Yavuz, • Göknur Özaydın Yavuz, ๑ Murat Öztürk, (1) Remzi Erten*}

Van Yüzüncü Yıl University Faculty of Medicine, Department of Dermatology; *Department of Pathology, Van, Turkey

Keywords: Syringocystadenoma papilliferum, axilla, hamartomatous adnexal tumor

Anahtar Kelimeler: Siringokistadenoma papilliferum, aksilla, hamartomatöz adneksiyal tümör

\section{To The Editor,}

Syringocystadenoma papilliferum (SCAP) is a benign hamartomatous adnexal tumor which usually develops in the form of nodules and plaques. It has been reported to be associated with a nevus sebaceous in $40 \%$ of cases. Lesions are mostly found on the head and neck region, they are rarely seen elsewhere. Among the plaque, solitary nodular, and linear forms, the linear variant is rare ${ }^{1,2}$. We hereby present a very rare case in the form of papulonodules with linear arrangement on the axilla.

A 14-year-old female patient was admitted to our outpatient clinic for multiple asymptomatic papules over the left axilla present since birth. The lesions had gradually progressed in size. There was no family history. On dermatological examination, we found a linear distribution of plaques on the left axilla. These were about $5 \mathrm{~cm}$ in length and made of papules and nodules in papillomatous structure, having the same color of the skin or transparent at some places (Figure 1). Histopathological examination of an excisional biopsy specimen from a papule showed the presence of papillary structures beneath the epidermis which were covered with a cuboidal epithelium and contained plasma cells (Figure 2). Based on the clinical and histopathological findings, the patient was diagnosed with SCAP and referred to plastic surgery for total excision of the lesion. Informed consent was obtained.

SCAP was first identified by John Stokes in 1917 as "nevus syringocystadenomateous papilliferum". It is a rare cutaneous adnexal neoplasm with a variable clinical presentation and characteristic histology. The tumor usually presents as skincolored, pink plaques/nodules, or as a single nodule. Its surface can be verrucous, papillary, hyperkeratotic, or moist ${ }^{1-3}$. SCAP is a rarely seen benign tumor which is present either at birth in $50 \%$ of cases or develops in early childhood, before puberty in $15-30 \%{ }^{1}$. While it shows a high predilection for the scalp and face, it occasionally affects the chest, back, abdominal wall, upper arms, nipples, eyelids, external auditory canal, scrotum, and the thighs ${ }^{1-5}$.

Address for Correspondence/Yazışma Adresi: Serap Güneș Bilgili MD, Van Yüzüncü YIl University Faculty of Medicine, Department of Dermatology, Van Turkey Phone: +90 5053112853 E-mail: drserapgunes@yahoo.com

Received/Geliş Tarihi: 18.01.2018 Accepted/Kabul Tarihi: 03.12.2018 ORCID ID: orcid.org/0000-0002-4685-885X

(C) Copyright 2019 by Turkish Society of Dermatology and Venereology

Turkderm-Turkish Archives of Dermatology and Venereology published by Galenos Yayınevi. 


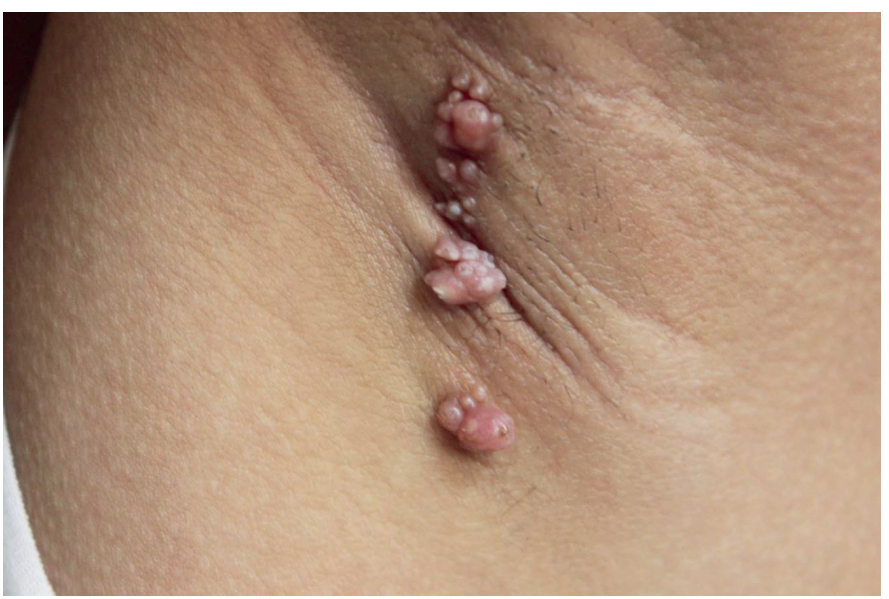

Figure 1. Linear series of plaques on the left axilla, c. $5 \mathrm{~cm}$ in length and made of papules and nodules in papillomatous structure in skin color or transparent at places

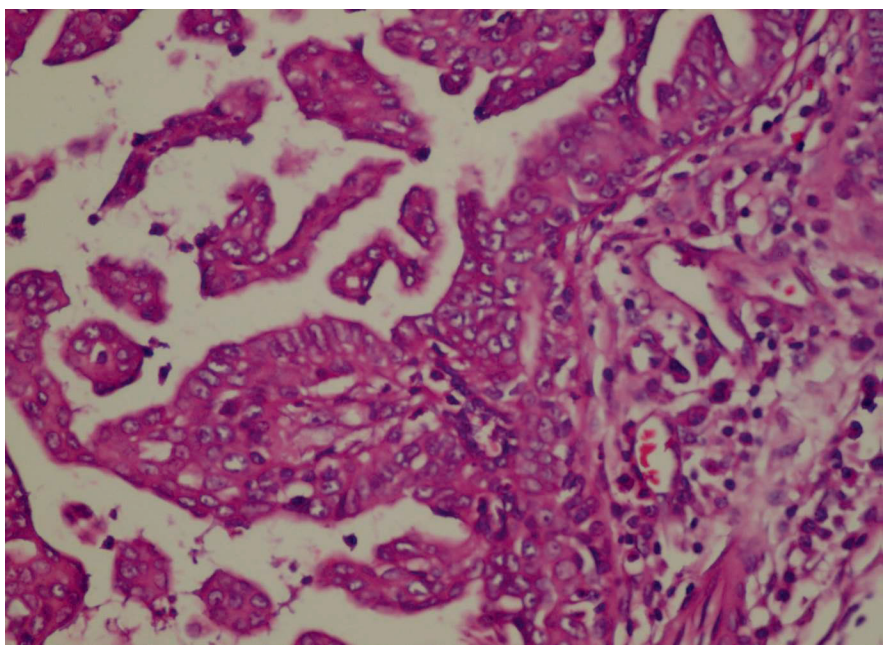

Figure 2. Papillary structures beneath the epidermis covered with a multi-row cuboidal epithelium (hematoxylin and eosin, x400)

Three clinical forms have been identified: plaque, solitary nodular, and linear. Linear variant is rare; only 14 cases of linear SCAP have been reported by $2013^{6}$.

Regardless of their clinical type, lesions usually present more or less with the same histopathologic features and prognosis. Histopathology typically shows cystic invaginations and malformed sebaceous glands, with papillomatosis present in varying degrees ${ }^{7,8}$.

Its histogenesis is still debated ${ }^{2,3}$. SCAP develops de novo or through an organoid nevus like the nevus sebaceous of Jadassohn (in 30$40 \%$ of cases) $)^{2,4}$. It is argued that SCAP develops from pluripotent cells with a potential for apocrine and eccrine differentiation, where the former is more common ${ }^{6}$. Shah et al. ${ }^{7}$ reported PTCH and p16 mutations. In adulthood, various benign or malign lesions may develop on SCAP ${ }^{5}$. Malign transformation is seen in $10 \%$ of cases and it usually presents itself as a basal cell carcinoma, but sometimes it grews into squamous cell carcinoma and rarely into syringocystadenocarcinoma papilliferum ${ }^{5,8}$. Ulceration or rapid growth of a previously existing tumor is indicative of a malign transformation".

The differential diagnosis of SCAP includes hidradenoma papilliferum, papillary eccrine adenoma, warty dyskeratoma and inverted follicular keratosis ${ }^{2,7}$.

SCAP is treated by performing an excisional biopsy, which also confirms the diagnosis. In anatomic areas not suitable for excision and grafting such as the head and neck, $\mathrm{CO}_{2}$ laser excision is a clinical treatment option. Mohs micrographic surgery is also known to achieve successful results in the treatment of SCAP'.

\section{Ethics}

Informed Consent: Informed consent was obtained.

Peer-review: Externally peer-reviewed.

\section{Authorship Contributions}

Concept: S.G.B., G.Ö.Y., Design: G.Ö.Y., I.H.Y., Data Collection or Processing: M.Ö., R.E., Analysis or Interpretation: I.H.Y., G.Ö.Y., Literature Search: M.Ö., Writing: S.G.B., M.Ö.

Conflict of Interest: No conflict of interest was declared by the authors.

Financial Disclosure: The authors declared that this study received no financial support.

\section{References}

1. Behera $\mathrm{M}$, Chatterjee $\mathrm{S}$. A case of syringocystadenoma papilliferum of eyelid with literature review. Indian J Ophthalmol 2015;63:550-1.

2. $\mathrm{Xu} \mathrm{D}, \mathrm{Bi}$, Lan $H$, et al. Syringocystadenoma papilliferum in the right lower abdomen: a case report and review of literature. Onco Targets Ther 2013;6:233-6.

3. Dufrechou L, Acosta A, Beltramo $P$, et al. Syringocystadenoma papilliferum arising on the scrotum. Pediatr Dermatol 2013;30:12-3.

4. Khurana VK, Mehta RK, Chaudhary D, et al. A case of syringocystadenoma papilliferum on lower leg: A rare location. Indian J Dermatol 2013;58:405.

5. Duran $M$, Üstünyurt $E$, Turgut $A$, et al. Syringocystadenoma papilliferum in an unusal location on vulva: a case report. J Clin Anal Med 2013;4(suppl 4):392-3.

6. Chauhan A, Gupta L, Gautam RK, et al. Linear syringocystadenoma papilliferum: a case report with review of literature. Indian J Dermatol 2013;58:409.

7. Shah PA, Singh VS, Bhalekar $S$, et al. Syringocystadenoma papilliferum: a rare case report with review of literature. J Sci Soc 2016;43:96-8.

8. Chandramouli M, Sarma D, Tejaswy K, et al. Syringocystadenoma papilliferum of the scalp arising from a nevus sebaceous. J Cutan Aesthet Surg 2016;9:204-6. 